\title{
İran'daki Devrimin İran Ermenileri Üzerindeki Sarsıcı Etkisi
}

\section{The Shocking Effect of the Revolution in Iran on Iranian Armenians}

\section{Hraçik Rupeni Simonyan, 1905-1912 Tt. Barsgagan Heğapoğutyunı Yev} Hayerı (1905-1912 Yılları Arasında İan Devrimi ve Ermeniler), Erivan, Erivan Devlet Üniversitesi Yayınları, 2017.

Haçadur NERSESOĞLU* (D)

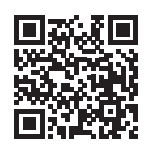

"istanbul, Türkiye

ORCID: H.N. 0000-0002-0193-1873

Sorumlu yazar/Corresponding author: Haçadur Nersesoğlu, İstanbul, Türkiye

E-posta/E-mail: hanersosoglu@hotmail.com

Başvuru/Submitted: 05.04 .2021

Kabul/Accepted: 15.12 .2021

Atıf/Citation: Nersesoglu, Hacadur. "Iran'daki Devrimin Iran Ermenileri Üzerindeki Sarsıcı Etkisi." Hraçik Rupeni Simonyan'ın"1905 - 1912 Tt. Barsgagan Heğapoğutyunı Yev Hayerı [1905 - 1912 Yılları Arasında İran Devrimi ve Ermeniler]" adlı eserinin değerlendirmesi." Yakın Dönem Türkiye Araștırmalarr-Recent Period Turkish Studies 40 (2021): 319-323.

https://doi.org/10.26650/YTA2021-910167
Anahtar Kelimeler: İran Devrimi, İran Ermenileri, Yeprem Han Tavityan, $1905-1912$

Keywords: Iranian Revolution, Iranian Armenians, Armenia, Yeprem Khan Tavityan, $1905-1912$

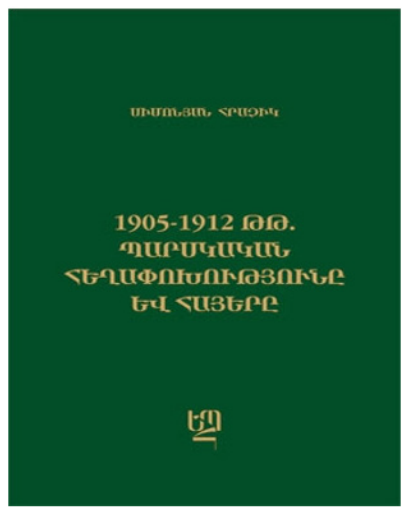




\section{Giriş}

XIX. yüzyıldan itibaren İngiltere, Fransa ve Rusya'nın İran üzerindeki nüfuz mücadeleleri, İran'ın zorlu bir süreç yaşamasına neden olmuştur. Bu arada İran halkının Batıya ait siyasi kavram ve unsurlarla tanışmaya başlaması, 1906 yılında Meşrutiyet hareketinin yaşanmasına zemin hazırlamıştır. ${ }^{1}$ İran Meşrutiyet hareketi ve akabinde yaşanan gelişmeler, birçok kaynakta yer almıştır. Bu kaynaklardan birisi de Prof. Dr. Hraçik Rupeni Simonyan'ın² kaleme aldığ1 "1905-1912 Tt. Barsgagan Heğapoğutyunı Yev Hayerı"dır. Eser, Ermeni Tarihçiler nezdinde, Ermenistan-İran ilişkileri konusunda önemli bir kaynak olarak kabul edilmektedir. İran Devriminin gerçekleştiği süreçte Ermenilerin durumunun ele alındığı eser, Erivan Devlet Üniversitesi tarafından araştırma yapan akademisyenlere yardımcı olması amacıyla yayınlanmıştır. Dört bölümden oluşan eserde birçok alt başlık kullanılarak, 1905-1912 yılları arasında yaşanan olaylardaki detayların fark edilmesi hedeflenmiştir.

Arşiv kaynakları ve İran'da yayınlanan dönemin Ermenice gazeteleri, eserin temel kaynaklarını oluşturmaktadır. Ermenice eserlerin yanı sıra bazı bölümlerde Rus ve İngiliz kaynaklarına da yer verilmiştir. Söz konusu kaynaklar, olayların karşılaştırılması amacıyla değil, sadece olay örgüsündeki önemli noktaların vurgulanması için kullanılmıştır. Eser bünyesinde bazı telgraf ve belgeler alıntılanmıştır. Bunun yanı sıra devrimin gerçekleştiği coğrafyada yaşayan Ermeni, Acem, Türk ve Kürt ilişkilerinde meydana gelen kırılmalar da mercek altına alınmıştır.

Eserin önsöz bölümünü kaleme alan Doç. Dr. Levon Avedisyan, Hraçik Rupeni Simonyan'ın Ermeni tarihçiliğinde önemli bir yerinin olduğunu belirtmiştir. Yazarın eserlerinden bazılarına yer veren Avedisyan, "1905-1912 Tt. Barsgagan Heğapoğutyunı Yev Hayer"in Ermeni ve Acem okuyucular için kapsamlı bir eser olduğundan bahsetmiştir. Avedisyan, İran Devrimi'nin önemli simalarından Yeprem Han Tavityan'ın eserde her yönüyle detaylı bir şekilde incelendiğini okuyuculara iletmiştir. Önsözün son

1 Kaan Dilek “İran'da Meşrutiyet Hareketi ve Dönemin Siyasi Gelişmeleri”, Akademik Orta Doğu Dergisi, Cilt: 2, Sayı: 1, 2007, s. 50.

2 Prof. Dr. Hraçik Rupeni Simonyan, 1952 yılında Erivan Devlet Üniversitesi, Tarih bölümünden mezun olmuştur. Ermenistan Komünist Partisine üye olan Simonyan, farklı bilim kuruluşlarda görev almış, 1971 yılında ise Profesör ünvanını almaya hak kazanmışı. Devlet ödülü sahibi de olan Simonyan'ın 30 civarndaı monografisi ve 400'ü aşkın bilimsel makalesi bulunaktadır. 2016 yılında vefat eden Simonyanın bazı eserleri Turk -Haygagan Haraprutyunneri Badmutyunits [Türk - Ermeni İlişkilerinin Tarihi], "AzadakrutyanBaykari Uğinerum [Bağımsızlık Mücadelesi Yolunda] (Beş cilt halinde yayınlanmıştır.) ve 1912 -1913 Palganyan Baderazmnerı Yev Hayerı [1912 - 1913 Balkan Savaşı ve Ermeniler] 'dir.

Emma Gosdantyan, "Akademigos Hraçik Simonyan [Akademisyen Hraçik Simonyan]”, Badmapanasiragan Hantes [Tarih-Filoloji Dergisi], Sayı: 3, Erivan, 2008, s. 284 - 287. 
kısmında devrimle ilgili düşüncelerini aktaran Avedisyan, meşrutiyetin fayda sağlamadığını, İran'da hırsızlık ve gasp olaylarının arttığını vurgulayarak, İran halkının ağır bir yükün altına girdiğini ifade etmiştir.

Eserin birinci bölümünde, 1905 yılında gerçekleşen Rus Devrimi’ni, 1789 Fransız Devrimi'yle karşılaştıran yazar, kıta Avrupası'nda meydana gelen değişimlerin doğu topraklarında aynı etkiyi gösteremediğini belirterek bu durumu, doğu ülkelerinin çoğunluğunun Müslüman olmasına bağlamıştır. Bölümde Rus Devrimi’nin olumsuz sonuçlarına değinilerek, Devrimin komşu ülke İran’a olan etkileri mercek altına alınmıştır. Ayrıca, devrimin gerçekleşmesinde bir diğer etmen olarak İngilizlerin faaliyetleri gösterilmiştir.

1906 yılında ilk meclisin açılması ve anayasa çalışmaları inceleyen yazar, Taşnaksutyun Partisi'nin Meşrutiyet hareketini desteklemelerinin nedenlerini, kendi yayın organları olan Troşak [Bayrak] gazetesinin yeniden yayınlanmasını sağlamak, Rusya'nın baskılarını bertaraf ederek İran'da yaşayan Ermenilerin refah seviyesini yükseltmek ve bu amaçla ülkenin güvenliğini sağlamak şeklinde belirtmiştir. Söz konusu bölümde devrimin başarıya ulaşması ve Meclisin açılmasının ardından Mıgırdiç Tüm Ermeniler Katolikosu'nun meclise 10 Mayıs 1907 tarihli bir telgraf iletmesi dikkat çeken önemli detaylardan biridir. Katolikos telgrafta, meydana gelen devrimden büyük mutluluk duyduğunu belirterek, meclisin Ermenilerle İranlılar arasında ayrımcılık yapmayacağını, bu iyi koşullardan Ermenilerin de yararlanmasını temenni ettiğini ifade etmiştir.

1907 yılından itibaren yaşanan gelişmelerin aktarıldığı ikinci bölümde İngiltere, Rusya ve Fransa arasında 31 Ağustos 1907 tarihinde imzalanan Britanya - Rusya Antantının İran için ileride büyük bir tehlike oluşturacağı yorumunda bulunulmuştur. Söz konusu Antantın imzalanasının akabinde İran topraklarının üç bölüme ayrıldığını belirten yazar, Kuzeyde Rus nüfuz alanı, Güneyde İngiltere nüfuz alanı ve İran'ın orta kısımlarının ise tarafsız bölge olduğunu, ayrıca Antantın Tahran meclisinin bilgisi dışında gerçekleştiğini ifade etmiştir. Yaşanan gelişmelerin ardından Troşak isimli gazetenin haberine yer verilmiş, haberde İran Meclisinin zor durumda olduğu ve artık basabileceği bir toprağının kalmadığı bildirilmiştir.

Söz konusu antantın ardından Osmanlı Devleti'nin İran topraklarından vazgeçmediği, Urmiye'nin kuzeydoğusunda yer alan bölgeleri ele geçirmeyi hedeflediği belirtilmiştir. Bunun akabinde Osmanlı Devleti ile bölgedeki Kürtler ve Ermeniler arasında yaşanan toprak krizi ve yansımaları detaylı bir şekilde okuyuculara aktarılmıştır. Meşrutiyetin 
sağlam temeller üzerine kurulmadığını belirten yazar, Muzaffereddin Şah'ın vefatının ardından oğlu Muhammed Ali Şah'ın tahta çıktı̆̆ını ifade etmiştir. Muhammed Ali Şah'ın meşrutiyet karşıtı olmasını hatırlatan yazar, Rusların desteğiyle askeri darbe kararı aldığını, bu amaçla 1908 yılında faaliyetlerine başladığını ve meşrutiyet taraflarını bertaraf ederek ülkede istibdat dönemini başlattığını bildirmiştir. Osmanlı, İran ve Rusya Ermenilerinin durumunun belirsizlik içinde geçtĭgi yorumunda bulunan yazar, Ermenilere karşı yapılan iyi muamelelerin sadece göstermelik olduğunu, söz konusu dönemden itibaren Ermenilerin birçok olumsuz durumla karşılaşacaklarını bildirerek bölümü sonlandırmıştır.

Muhammed Ali Şah'ın devrilmesinin ardından yaşananların mercek altına alındığı üçüncü bölümde, Meclisin tekrar oluşturulmaya başlandığı ancak bu süre zarfinda meşrutiyet taraftarlarının büyük bir zafer elde edemedikleri vurgulanmıştır. Yazar bu düşüncesini desteklemek amaciyla Tiflis'te yayınlanan Ermeni basın organlarından Surhantag [Posta] gazetesinin haberine yer vermiştir. Devrimin başarılı olsa da halk arasında meşrutiyetin tam anlamıyla benimsenemediğini belirten gazete, meşrutiyet karşıtlarının ayaklanmaya devam ettikleri bilgisini okuyucularla paylaşmıştır.

Yönetim organlarının oluşturulma sürecinin ele alındığı bölümde yaşanan gelişmelerin, uzun bir süre Bolşevik basın organları olan Nor Hosk [Yeni Söz], Gaydz [Kıvılcım], Bakinskiy Rabochiy [Bakü İşçisi] ve Gudok gibi gazeteler tarafından yakından takip edildiği bilgisi yer almıştır. Yazar, bu süreçte Ermeni temsilcilerin Mecliste yer alma problemine değinmiştir. Yaşanan gelişmelerin ardından İranlı Ermenilerin çoğunlukta yaşadığı Tebriz, Urmiye, Salmast ve Hoy gibi yerlerin yönetiminde söz sahibi olmaya başladıkları belirtilmiştir.

Dördüncü bölümde eski rejimi destekleyenlerle meşrutiyetçiler arasında yaşanan krizin ciddi boyutlara ulaştığını bildiren yazar, 1910 yılında Muhammed Ali Şah'ın yeniden güçlenmiş olan anayasal devleti ortadan kaldırmak amacıyla yürüttüğü faaliyetlere ve İran Anayasa Devriminin önde gelen isimlerinden Taşnaksutyun Partisi üyesi olan Yeprem Han'ın mücadelesine yer vermiştir. Yeprem Han'ın öngörü sahibi olduğunu belirten yazar, Muhammed Ali Şah ve destekçilerinin Tahran'a saldırmak için oluşturduğu güçlerini yendiğini ifade etmiştir. Yeprem Han'ın Ermeni ve Acemlerden oluşan güçleriyle üç cephede mücadele etmek zorunda kaldığını belirten yazar, mücadele sonunda Muhammed Ali Şah'ın bir kez daha ülkeyi terk ederek Rusya'ya kaçtığını bildirmiştir.

Yazar bu bölümde, söz konusu mücadele esnasında, 26 Mayıs 1912 yılında Şahın güçleri tarafindan öldürülen Yeprem Han'ın, meşrutiyetçiler için büyük bir kayıp 
olduğunu ifade etmiştir. Devrimde yer alan Ermenilerin önemine değinen yazar, tüm çabalara rağmen devrimin tam manasıyla başarılı olmamasını emperyalist güçlerin İran üzerinde yürüttükleri faaliyetlere, aynı zamanda İran halkının büyük bir kısmının yaşanan olaylarda tarafsız kalmasına bağlamıştır. Yazar bu koşullara rağmen, Yeprem Han’ın monarşinin yeniden yönetim biçimi olmaması için kahramanca mücadele ettiğini vurgulamıştır.

Eserin sonunda genel bir değerlendirmede bulunan yazar, devrimin İran Ermenilerine herhangi bir faydasının olmadığını, bunun yanı sıra Ermenilerin mal ve can kaybı yaşadıklarını ifade etmiştir. Yazara göre Ermeniler söz konusu harekete destek vermeselerdi ve tarafsızlıklarını korusalardı yaşanan çatışmalardan fazla etkilenmeyeceklerdi. Devrimin ardından uzun yıllar çatışmaların devam ettiğini hatırlatan yazar, devrimin bir son olmadığ1 yorumunda bulunarak eserini sonlandırmıştır.

Türkçe kaynaklar incelendiğinde, 1906 İran Devrimi ve akabinde yaşanan süreçlerle ilgili eser sayısının yetersiz olduğu görülmektedir. "1905 - 1912 Tt. Barsgagan Heğapoğutyunı Yev Hayerı”, dönemin aydınlatılması açısından büyük bir önem arz ettiğinden, eserin Türkçeye çevrilerek konuyla ilgili çalışma yapmak isteyen akademisyenler için yardımcı bir kaynak olması muhtemeldir. Ayrıca eserde yer alan İran tarihiyle ilgili diğer Ermenice kaynaklar da değerlendirilmelidir. Ermenice kaynaklar dışında başka dillerde de kaleme alınan eserler Türkçeye çevrilerek İran tarihi çerçevesinde farklı konularda yeni eserler okuyucuların dikkatine sunulabilir. Eserlerin yanı sıra dönemin süreli yayınları ve arşiv belgelerinin değerlendirilmesi konunun her yönüyle analiz edilmesine yardımcı olacaktır.

\section{KAYNAKÇA}

\section{Araştırma Eserler}

Dilek, Kaan: “İran’da Meşrutiyet Hareketi ve Dönemin Siyasi Gelişmeleri”, Akademik Orta Doğu Dergisi, Cilt: 2, Say1: 1, 2007, s. 50 - 68.

Gosdantyan, Emma: "Akademigos Hraçik Simonyan [Akademisyen Hraçik Simonyan]”, Badmapanasiragan Hantes [Tarih - Filoloji Dergisi], Say1: 3, Erivan, 2008, s. 284 - 289. 
